\title{
Arousal Inhibitory Effect of Phlorotannins on Caffeine in Pentobarbital-Induced Mice
}

\author{
Suengmok Cho ${ }^{1}$, Hyejin Yang ${ }^{1}$, Minseok Yoon ${ }^{1}$, Jiyoung Kim ${ }^{1}$, Dongsoo Kim ${ }^{1}$, Jinkyung Kim ${ }^{2}$, \\ Seon-Bong $\mathrm{Kim}^{3 *}$ \\ ${ }^{1}$ Korea Food Research Institute, Seongnam 463-746, Korea \\ ${ }^{2}$ KGC Lifengin, Seoul 135-549, Korea \\ ${ }^{3}$ Department of Food Science and Technology, Pukyong National University, Busan 608-737, Korea
}

\begin{abstract}
Sleep is vital to maintain health and well-being; however, insomnia is currently a widespread health complaint worldwide. In particular, caffeine, a psychoactive component of coffee, tea, and caffeine beverages may lead to sleep disorders such as insomnia. In this study, our primary objective was to investigate the inhibitory effect of high-purity phlorotannin preparation (HP-PRT) on caffeine-induced wakefulness. The sleep test of pentobarbital-induced mice was used as an in vivo animal model. Caffeine (50 and $100 \mathrm{mg} / \mathrm{kg}$ ) showed significant arousal effects (an increase in sleep latency and a decrease in sleep duration). Co-administration of caffeine $(50 \mathrm{mg} / \mathrm{kg}$ ) and the sedative-hypnotic diazepam (DZP, $1 \mathrm{mg} / \mathrm{kg}$ ) did not result in similar arousal activity. HP-PRT (500 $\mathrm{mg} / \mathrm{kg}$ ) also inhibited caffeine-induced wakefulness. Our results suggest that HP-PRT would be a useful additive for developing coffee products without the arousal effect.
\end{abstract}

Key words: Phlorotannins, Somnogenic effect, Caffeine, Arousal effect, Pentobarbital-induced sleep test

\section{Introduction}

Sleep is vital to maintain health and well-being because of its primary function of providing rest and restoring the body's energy levels (Krueger et al., 2008). Sleep disorders impair not only cognitive and psychological functioning but also physical health (Brand and Kirov, 2011). In addition, obesity and cardiovascular disease are closely related to sleep disorders (Gangwisch et al., 2005; Wolk et al., 2005; Miller and Cappuccio, 2007).

Coffee is one of the most consumed beverages in the world (Tuomilehto et al., 2004), and has an arousal effect on the central nervous system (Davis et al., 2003). Caffeine, the major psychoactive constituent in coffee (Brown et al., 2001), induces wakefulness by inhibiting adenosine $\mathrm{A}_{2 \mathrm{~A}}$ receptors (Huang et al., 2005). According to the "Caffeine Intake by the U.S.
Population" report, the average amount of caffeine consumed is approximately $300 \mathrm{mg} /$ person/day (Somogyi, 2010). A large amount of caffeine may lead to sleep disorders, such as insomnia (Sanchez-Ortuno et al., 2005; Strassnig et al., 2006). Therefore, to identify foods, and their constituents, that can inhibit the arousal effect of caffeine would be promising from the perspective of the food industry.

In our previous studies (Cho et al., 2012a; Cho et al., 2012b), we have demonstrated that phlorotannin extracts from the brown alga Ecklonia cava induce sleep via modulation of the benzodiazepine site of the $\mathrm{GABA}_{\mathrm{A}}$ receptor. In the present study, the effect of phlorotannins on caffeine-induced wakefulness was evaluated using a pentobarbital-induced sleep test in mice.
http://dx.doi.org/10.5657/FAS.2014.0013

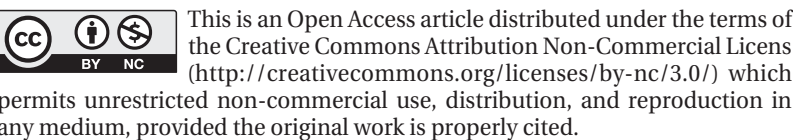

Received 06 July 2013; Revised 05 September 2013

Accepted 30 September 2013

*Corresponding Author

E-mail: owlkim@pknu.ac.kr 


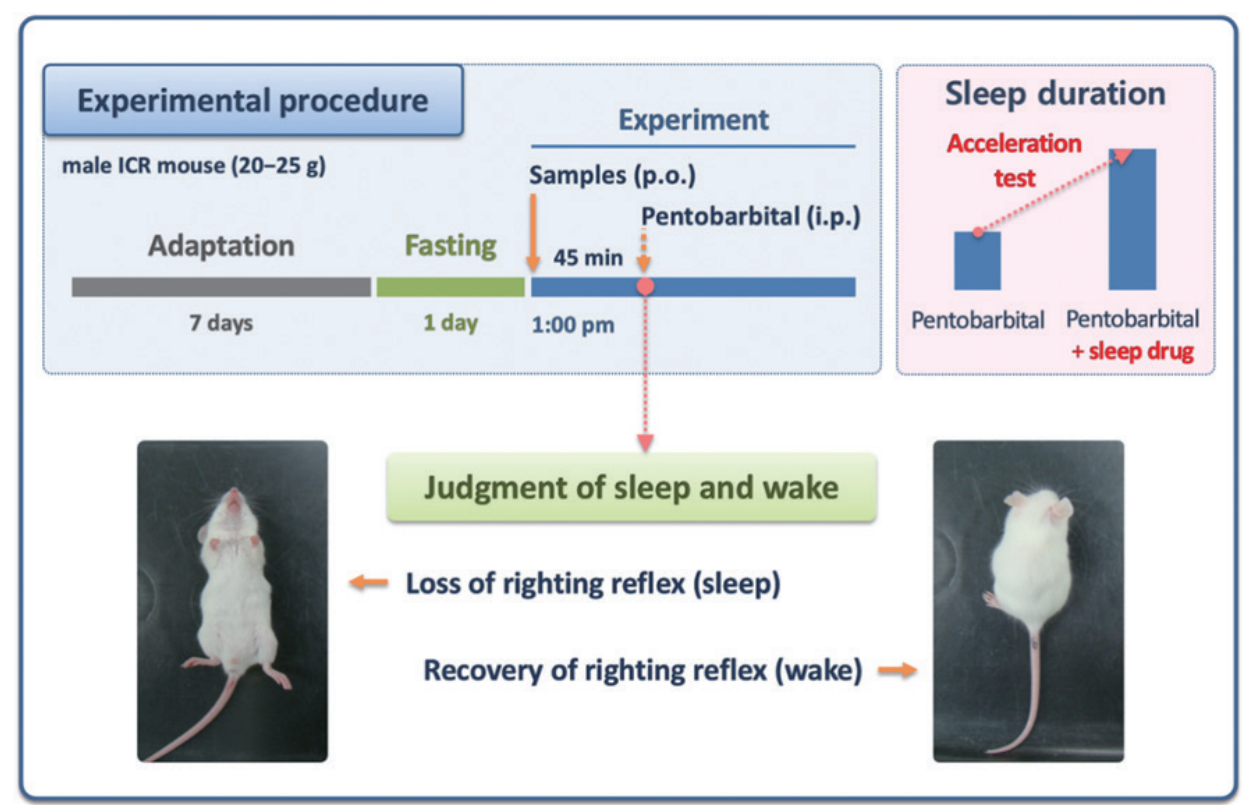

Fig. 1. The experimental procedure of the pentobarbital-induced sleep test in mice.

\section{Materials and Methods}

\section{Materials}

The high-purity phlorotannin preparation (HP-PRT, lot no. SD-GT-E-004) was obtained from S\&D Co., Ltd. (Yeongigun, Chungcheongnam-do, Korea). HP-PRT was purified from the ethanol extract of the brown alga Ecklonia cava, and was standardized to $67 \mathrm{mg} / \mathrm{g}$ dieckol. The total phlorotannin content of HP-PRT is $90 \%$ (900 mg phloroglucinol equivalents/g, w/w). Diazepam (DZP; Myungin Pharm. Co. Ltd., Seoul, Korea), a GABA $\mathrm{A}_{\mathrm{A}}$-benzodiazepine agonist, was used as a reference hypnotic drug. All other chemicals and reagents were of the highest grade available.

\section{Animals}

All procedures involving animals were conducted in accordance with the animal care and use guidelines of the Korea Food Research Institutional Animal Care and Use Committee (permission number: KFRI-M-12027). Every effort was made to minimize the number of animals used and any pain and discomfort that they might experience. ICR mice (male; 23-28 g; 4 weeks) were purchased from Koatech Animal Inc. (Pyeongtaek, Korea). The animals were housed in an insulated, soundproof recording room maintained at an ambient temperature of $23 \pm 0.5^{\circ} \mathrm{C}$, with a relative humidity $(55 \pm 2 \%)$ on an automatically controlled 12-h light/12-h dark cycle (lights on at 5:00). They had free access to food and water.

\section{Pentobarbital-induced sleep test}

For better understanding the pentobarbital-induced sleep test in mice, the experimental procedure is shown in Fig. 1. All samples were dissolved in $0.5 \%(\mathrm{w} / \mathrm{v})$ carboxymethyl cellulose (CMC)-physiological saline before use. Control mice $(0.5 \%$ CMC-saline, $10 \mathrm{ml} / \mathrm{kg})$ were tested in parallel with the animals receiving test sample treatment. All experiments were performed between 13:00 and 17:00, and mice were fasted for $24 \mathrm{~h}$ prior to the experiment. Test solutions were administered (post-oral injection, p.o.) to mice by using a sonde needle 30 min prior to the intraperitoneal injection (i.p.) of pentobarbital (42 $\mathrm{mg} / \mathrm{kg}$ ). Following the pentobarbital injection, the mice were placed in individual cages and observed for measurements of sleep latency and sleep duration. Observers were blinded to the individual treatments. The sleep latency was recorded from the time of pentobarbital injection to the time of sleep onset, and sleeping duration was defined as the difference in time between the loss and recovery of the righting reflex.

\section{Statistical analysis}

For multiple comparisons in the pentobarbital-induced sleep test, data were analyzed using one-way ANOVA followed by Dunnett's test. Comparisons between group data were analyzed using an unpaired Student's $t$-test. Differences with $p<0.05$ were considered statistically significant. The significance analysis was performed using Prism 5.0 (GraphPad Software Inc., San Diego, CA, USA). 

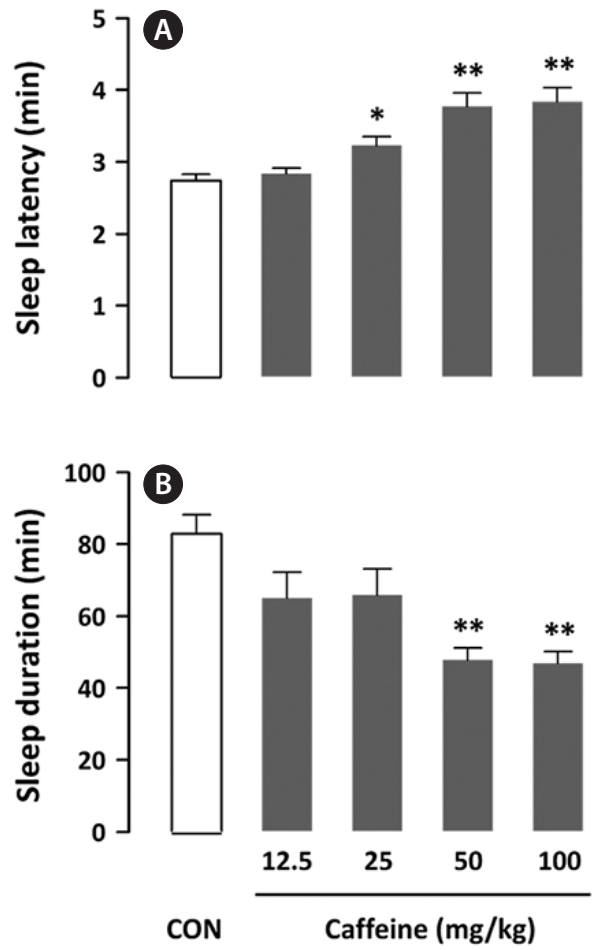

Fig. 2. Effects of caffeine on sleep latency (A) and sleep duration (B) in mice administered a hypnotic dose $(42 \mathrm{mg} / \mathrm{kg}$, i.p.) of pentobarbital. Mice received pentobarbital $30 \mathrm{~min}$ after oral administration (p.o.) of the control group (CON) and caffeine. Each column represents mean \pm SEM $(n=10) .{ }^{*} p<0.05,{ }^{* *} p<0.01$, significant difference as compared to the control group (Dunnett's test).

\section{Results and Discussion}

Although a large amount of caffeine intake is known to lead to sleep disorders such as insomnia, few studies have been conducted on foods and their constituents with inhibitory effects on caffeine-induced wakefulness. In this study, we evaluated the effect of HP-PRT with sedative-hypnotic activity on caffeine-induced wakefulness by using the pentobarbitalinduced sleep test in mice. This method is useful to evaluate in vivo hypnotic and arousal activities (Ma et al., 2009). It is important that the active compounds are able to pass the blood-brain barrier to produce hypnotic or arousal activities (Risa et al., 2004). Therefore, it is necessary to confirm activities through in vivo animal model assays (Fang et al., 2010).

To determine a statistically significant dosage of caffeine, its effects on sleep latency and sleep duration in mice were evaluated. With a hypnotic dose of pentobarbital $(42 \mathrm{mg} / \mathrm{kg})$, caffeine $(12.5,25,50$, and $100 \mathrm{mg} / \mathrm{kg}$, p.o.) produced a dosedependent increase in sleep latency and a decrease in sleep duration (Fig. 2). It showed a significant $(p<0.01)$ arousal activity from a concentration of $50 \mathrm{mg} / \mathrm{kg}$. According to the results of Huang et al. (2005), caffeine significantly produced arousal
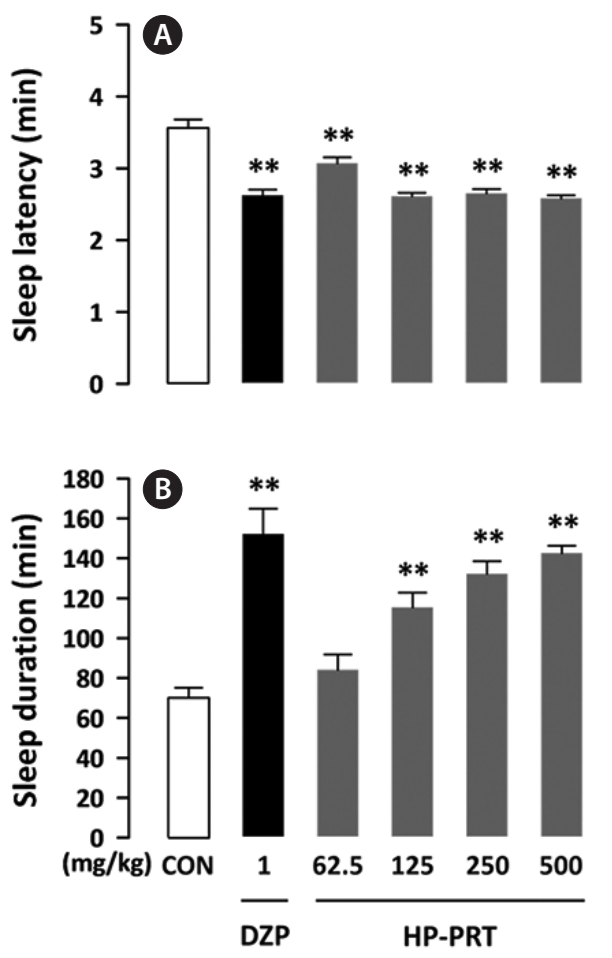

Fig. 3. Effects of high-purity phlorotannin preparation (HP-PRT) and diazepam (DZP) on sleep latency (A) and sleep duration (B) in mice administered a hypnotic dose $(42 \mathrm{mg} / \mathrm{kg}$, i.p.) of pentobarbital. Mice received pentobarbital $30 \mathrm{~min}$ after oral administration (p.o.) of samples. Each column represents mean \pm SEM $(n=10) .{ }^{*} p<0.01$, significant difference as compared to the control group (Dunnett's test).

activity in analysis of sleep-wake profile based on electroencephalography and electromyography. In this study, $50 \mathrm{mg} / \mathrm{kg}$ was selected as a dosage of caffeine for the experiment to test the inhibitory effects of phlorotannins. A dosage of HP-PRT was determined by testing four concentrations of $62.5,125$, 250 , and $500 \mathrm{mg} / \mathrm{kg}$. Diazepam (DZP), one of the most wellknown sedative-hypnotics, was tested as a positive control in parallel with HP-PRT. One $\mathrm{mg} / \mathrm{kg}$ of DZP has been tested as the positive control in the pentobarbital-induced sleep test (Amos et al., 2003; de Sousa et al., 2005). As expected, it was found that DZP (1 mg/kg, p.o.) significantly potentiated the pentobarbital-induced sleep in mice $(p<0.01)$ relative to the control group (Fig. 3). HP-PRT also caused a dose-dependent decrease in sleep latency (Fig. 3A) and an increase in sleep duration (Fig. 3B). Effect of HP-PRT on caffeine-induced wakefulness was evaluated at $500 \mathrm{mg} / \mathrm{kg}$ with the significant hypnotic activity similar to DZP at $1 \mathrm{mg} / \mathrm{kg}$.

The inhibitory effect of DZP, a positive control on caffeineinduced wakefulness, is shown in Fig. 4. DZP induces sleep via positive allosteric modulation of the benzodiazepine site of the $\mathrm{GABA}_{\mathrm{A}}$ receptor (Kopp et al., 2003; Tobler et al., 2001). As expected, administration of caffeine $(50 \mathrm{mg} / \mathrm{kg})$ alone 

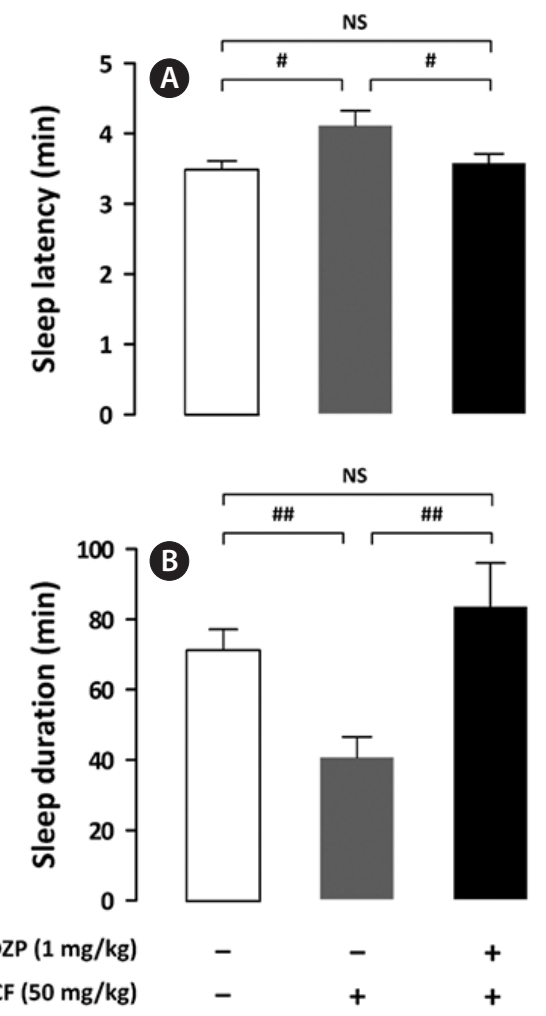

Fig. 4. Effects of co-administration of diazepam (DZP, $1 \mathrm{mg} / \mathrm{kg}$ ) and caffeine $(C F, 50 \mathrm{mg} / \mathrm{kg})$ on sleep latency (A) and sleep duration (B) in mice administered a hypnotic dose $(42 \mathrm{mg} / \mathrm{kg}$, i.p.) of pentobarbital. Each column represents mean \pm SEM $(n=10) .{ }^{*} p<0.05,{ }^{\# \#} p<0.01$, significant difference between each group (unpaired Student's $t$-test). NS, not significant.

showed significant arousal effects; however, sleep latency and sleep duration of mice treated with both DZP $(1 \mathrm{mg} / \mathrm{kg})$ and caffeine were similar to those of the control group. HPPRT $(500 \mathrm{mg} / \mathrm{kg}$ ) also reversed the arousal effect of caffeine (Fig. 5). The pentobarbital-induced sleep test using rodents is a useful in vivo assay for evaluating hypnotic or arousal effect. Pentobarbital, an anesthetic, produces hypnosis and anesthesia by modulating the barbiturate site of $\mathrm{GABA}_{\mathrm{A}}$ receptor (Gerak et al., 2004). Regardless of molecular mechanisms of sleep-wake regulation, hypnotic or arousal compounds can accelerate or decelerate the pentobarbital-induced sleep. In this study, arousal effect of caffeine via the adenosine $\mathrm{A}_{2 \mathrm{~A}}$ receptor was offset by hypnotic effect of DZP and HP-PRT via the benzodiazepine site of the $\mathrm{GABA}_{\mathrm{A}}$ receptor. Therefore, this offset did not alter duration and latency of the pentobarbital-induced sleep. In addition, according to the report by El Yacoubi et al. (2003), caffeine reduced the hypnotic effect of alcohol by modulating the $\mathrm{GABA}_{\mathrm{A}}$ receptor (Koob, 2004; Lobo and Harris, 2008; Kumar et al., 2009).
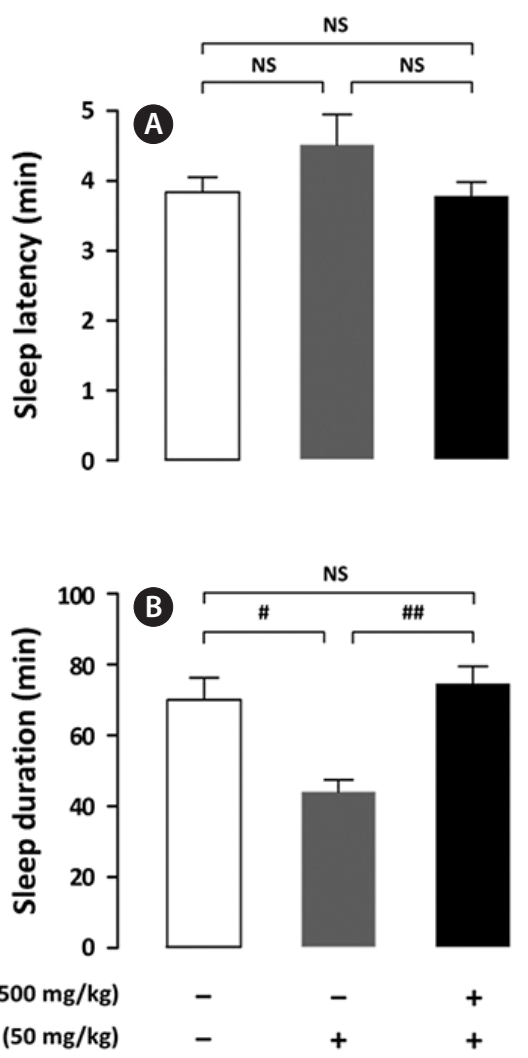

Fig. 5. Effects of co-administration of high-purity phlorotannin preparation (HP-PRT, $500 \mathrm{mg} / \mathrm{kg}$ ) and caffeine (CF, $50 \mathrm{mg} / \mathrm{kg}$ ) on sleep latency (A) and sleep duration (B) in mice administered a hypnotic dose (42 $\mathrm{mg} / \mathrm{kg}$, i.p.) of pentobarbital. Each column represents mean \pm SEM $(n=10) .{ }^{*} p<0.05,{ }^{\# \#} p<0.01$, significant difference between each group (unpaired Student's $t$-test). NS, not significant.

In this experiment, no adverse effects were observed following HP-PRT administration. It is known that benzodiazepine agents, such as DZP increase non-rapid eye movement sleep without altering rapid eye movement sleep (Qiu et al., 2009) but decrease delta activity, an indicator of sleep quality (Bastien et al., 2003). HP-PRT does not alter delta power (data not shown) and would thus be a better agent for inhibiting caffeine-induced wakefulness. Phlorotannins, which are oligomers and polymers of phloroglucinol (1,3,5-tri-hydroxybenzene), have a brown color and a bitter taste (Shibata et al., 2002). Their sensory characteristics would be suitable as an additive to coffee. In addition, phlorotannins have various biological activities, such as antioxidative (Zou et al., 2008), anti-inflammatory (Kim et al., 2009), antibacterial (Nagayama et al., 2002), and antiallergic (Sugiura et al., 2006) effects. Therefore, HP-PRT may be a good additive for the preparation of coffee products without an arousal effect. Further studies are needed to evaluate the effects of co-administration of HP-PRT and caffeine on sleep-wake architecture and profile. 


\section{Acknowledgements}

This study was supported by grants from the Korea Food Research Institute (E0131402) and Korea Small and Medium Business Administration (S2060252).

\section{References}

Amos S, Binda L, Chindo BA, Tseja A, Odutola AA, Wambebe C and Gamaniel K. 2003. Neuropharmacological effects of Hibiscus sabdariffa aqueous extract. Pharm Biol 41, 325-329.

Bastien CH, LeBlanc M, Carrier J and Morin CM. 2003. Sleep EEG power spectra, insomnia, and chronic use of benzodiazepines. Sleep 26, 313-317.

Brand S and Kirov R. 2011. Sleep and its importance in adolescence and in common adolescent somatic and psychiatric conditions. Int J Gen Med 4, 425-442.

Brown J, Kreiger N, Darlington GA and Sloan M. 2001. Misclassification of exposure: coffee as a surrogate for caffeine intake. Am J Epidemiol 153, 815-820.

Cho S, Han D, Kim SB, Yoon M, Yang H, Jin YH, Jo J, Yong H, Lee SH, Jeon YJ and Shimizu M. 2012b. Depressive effects on the central nervous system and underlying mechanism of the enzymatic extract and its phlorotannin-rich fraction from Ecklonia cava edible brown seaweed. Biosci Biotechnol Biochem 76, 163-168.

Cho S, Yang H, Jeon YJ, Lee CJ, Jin YH, Baek NI, Kim D, Kang SM, Yoon M, Yong H, Shimizu M and Han D. 2012a. Phlorotannins of the edible brown seaweed Ecklonia cava Kjellman induce sleep via positive allosteric modulation of gamma-aminobutyric acid type A-benzodiazepine receptor: A novel neurological activity of seaweed polyphenols. Food Chem 132, 1133-1142.

Davis JM, Zhao Z, Stock HS, Mehl KA, Buggy J and Hand GA. 2003. Central nervous system effects of caffeine and adenosine on fatigue. Am J Physiol Regul Integr Comp Physiol 284, 399-404.

De Sousa FCF, Pereira BA, Lima VTM, Lacerda CDG, Melo CTV, Barbosa-Filho JM, Vasconcelos SMM and Viana GSB. 2005. Central nervous system activity of yangambin from Ocotea duckei Vattimo (Lauraceae) in mice. Phytother Res 19, 282-286.

El Yacoubi M, Ledent C, Parmentier M, Costentin J and Vaugeois JM. 2003. Caffeine reduces hypnotic effects of alcohol through adenosine $\mathrm{A}_{2 \mathrm{~A}}$ receptor blockade. Neuropharmacology 45, 977-985.

Fang XS, Hao JF, Zhou HY, Zhu LX, Wang JH and Song FQ. 2010. Pharmacological studies on the sedative-hypnotic effect of Semen Ziziphi spinosae (Suanzaoren) and Radix et Rhizoma Salviae miltiorrhizae (Danshen) extracts and the synergistic effect of their combinations. Phytomedicine 17, 75-80.

Gangwisch JE, Malaspina D, Boden-Albala B and Heymsfield SB. 2005. Inadequate sleep as a risk factor for obesity: analyses of the NHANES I. Sleep 28, 1289-1296.

Gerak LR, Stevenson MW, Winsauer PJ and Moerschbaecher JM. 2004. Effects of pregnanolone alone and in combination with other positive $\mathrm{GABA}_{\mathrm{A}}$ modulators on complex behavior in rats. Psychopharmacology 173, 195-202.
Huang ZL, Qu WM, Eguchi N, Chen JF, Schwarzschild MA, Fredholm BB, Urade $Y$ and Hayaishi O. 2005. Adenosine $A_{2 A}$, but not $A_{1}$, receptors mediate the arousal effect of caffeine. Nat Neurosci 8 , 858-859.

Kim AR, Shin TS, Lee MS, Park JY, Park KE, Yoon NY, Kim JS, Choi JS, Jang BC, Byun DS, Park NK and Kim HR. 2009. Isolation and identification of phlorotannins from Ecklonia stolonifera with antioxidant and anti-inflammatory properties. J Agric Food Chem 57, 3483-3489.

Koob GF. 2004. A role for GABA mechanisms in the motivational effects of alcohol. Biochem Pharmacol 68, 1515-1525.

Kopp C, Rudolph U, Keist R and Tobler I. 2003. Diazepam-induced changes on sleep and the EEG spectrum in mice: role of the $\alpha 3$ $\mathrm{GABA}_{\mathrm{A}}$ receptor subtype. Eur J Neurosci 17, 2226-2230.

Krueger JM, Rector DM, Roy S, Van Dongen HP, Belenky G and Panksepp J. 2008. Sleep as a fundamental property of neuronal assemblies. Nat Rev Neurosci 9, 910-919.

Kumar S, Porcu P, Werner DF, Matthews DB, Diaz-Granados JL, Helfand RS and Morrow AL. 2009. The role of $\mathrm{GABA}_{\mathrm{A}}$ receptors in the acute and chronic effects of ethanol: a decade of progress. Psychopharmacology 205, 529-564.

Lobo IA and Harris RA. 2008. GABA A receptors and alcohol. Pharmacol Biochem Behav 90, 90-94.

Ma Y, Ma H, Eun JS, Nam SY, Kim YB, Hong JT, Lee MK and Oh KW. 2009. Methanol extract of Longanae Arillus augments pentobarbital-induced sleep behaviors through the modification of GABAergic systems. J Ethnopharmacol 122, 245-250.

Miller MA and Cappuccio FP. 2007. Inflammation, sleep, obesity and cardiovascular disease. Curr Vasc Pharmacol 5, 93-102.

Nagayama K, Iwamura Y, Shibata T, Hirayama I and Nakamura T. 2002. Bactericidal activity of phlorotannins from the brown alga Ecklonia kurome. J Antimicrob Chemother 50, 889-893.

Qiu MH, Qu WM, Xu XH, Yan MM, Urade Y and Huang ZL. 2009. $\mathrm{D}_{1} / \mathrm{D}_{2}$ receptor-targeting L-stepholidine, an active ingredient of the Chinese herb Stephonia, induces non-rapid eye movement sleep in mice. Pharmacol Biochem Behav 94, 16-23.

Risa J, Risa A, Adsersen A, Gauguin B, Stafford GI, van Staden J and Jäger AK. 2004. Screening of plants used in southern Africa for epilepsy and convulsions in the $\mathrm{GABA}_{\mathrm{A}}$-benzodiazepine receptor assay. J Ethnopharmacol 93, 177-182.

Sanchez-Ortuno M, Moore N, Taillard J, Valtat C, Leger D, Bioulac B and Philip P. 2005. Sleep duration and caffeine consumption in a French middle-aged working population. Sleep Med 6, 247-251.

Shibata T, Fujimoto K, Nagayama K, Yamaguchi K and Nakayama T. 2002. Inhibitory activity of brown algal phlorotannins against hyaluronidase. Int J Food Sci Tech 37, 703-709.

Somogyi LP. 2010. Caffeine intake by the U.S. population, FDA comments. Subcontract No. 70000073494. FDA, Oakridge, USA, pp. 1-85.

Strassnig M, Brar JS and Ganguli R. 2006. Increased caffeine and nicotine consumption in community-dwelling patients with schizophrenia. Schizophr Res 86, 269-275.

Sugiura Y, Takeuchi Y, Kakinuma M and Amano H. 2006. Inhibitory effects of seaweeds on histamine release from rat basophile leuke- 
mia cells (RBL-2H3). Fisheries Sci 72, 1286-1291.

Tobler I, Kopp C, Deboer T and Rudolph U. 2001. Diazepam-induced changes in sleep: role of the alpha $1 \mathrm{GABA}_{\mathrm{A}}$ receptor subtype. Proc Natl Acad Sci USA 98, 6464-6469.

Tuomilehto J, Hu G, Bidel S, Lindström J and Jousilahti P. 2004. Coffee consumption and risk of type 2 diabetes mellitus among middleaged Finnish men and women. JAMA 291, 1213-1219.
Wolk R, Gami AS, Garcia-Touchard A and Somers VK. 2005. Sleep and cardiovascular disease. Curr Probl Cardiol 30, 625-662.

Zou Y, Qian ZJ, Li Y, Kim MM, Lee SH and Kim SK. 2008. Antioxidant effects of phlorotannins isolated from Ishige okamurae in free radical mediated oxidative systems. J Agric Food Chem 56, 7001-7009. 